\title{
Reason and Sentiment in Normative Disputes
}

\author{
Luís R. Cardoso de Oliveira' \\ 'Universidade de Brasília, Departamento de Antropologia, Brasília/DF, Brasil
}

\begin{abstract}
In the last fifty years, anthropology has engaged in intense debates about the rational grounds upon which ethnographic understanding rests. Whatever the particular stand taken by the respective interlocutors in these debates, the main reference shared by all interventions is the symbolic character of anthropological data and understanding. If that is so for any ethnographic context, the importance of focusing on the symbolic pre-structure of the lifeworld is even more significant when we look at normative disputes. This is because differently than assertoric statements about facts in the world, the meanings of norms exist prior to the research interests of the interpreter and lie first and foremost in the world views of the subjects who share them. My research about dispute resolution has shown that reason and sentiment often become entangled in these processes and their proper articulation is a condition for making the respective conflicts intelligible.
\end{abstract}

Keywords: reason; sentiment; disputes; United States; Australia; Brazil.

\section{Razão e Sentimento em Disputas Normativas}

\section{Resumo}

Nos últimos 50 anos a antropologia tem se envolvido em intensos debates sobre os princípios racionais que fundamentam a compreensão etnográfica. Qualquer que seja a particularidade da perspectiva adotada nesses debates, a principal referência compartilhada por todas as intervenções é o caráter simbólico dos dados e da compreensão antropológica. Se isso é sempre assim em qualquer contexto etnográfico, a importância do foco na pré-estrutura simbólica do mundo da vida é ainda mais significativa na análise de disputas normativas. Pois, diferentemente das locuções assertóricas sobre o mundo dos fatos, o significado das normas precede os interesses de pesquisa do intérprete, e se situa acima de tudo nas visões de mundo dos sujeitos que as compartilham. Minhas pesquisas sobre processos de resolução de disputas revelam que razão e sentimento estão frequentemente embaralhados, e sua articulação adequada é a condição para tornar inteligíveis os respectivos conflitos.

Palabras chave: razão; sentimento; disputas; Estados Unidos; Australia; Brasil. 


\section{Razón y sentimiento en disputas normativas}

\section{Resumen}

En los últimos cincuenta años la antropología se ha involucrado en intensos debates sobre los principios racionales que fundamentan la comprensión etnográfica. Cualquiera que sea la línea particular tomada por los respectivos interlocutores en estos debates, la referencia principal compartida por todas las intervenciones es el carácter simbólico de los datos antropológicos y de la comprensión. Si eso es así para cualquier contexto etnográfico, la importancia de centrarse en la pre-estructura simbólica del mundo de la vida es aún más significativa cuando miramos las disputas normativas. A diferencia de las declaraciones asertivas sobre hechos en el mundo, el significado de las normas es anterior a los intereses de investigación del intérprete y se encuentra ante todo en las visiones del mundo de los sujetos que las comparten. Mis esfuerzos de investigación sobre los procesos de resolución de disputas han demostrado que la razón y el sentimiento a menudo se enredan, y su articulación adecuada es la condición para hacer que los conflictos respectivos sean inteligibles.

Palabras clave: razón; sentimiento; disputas; Estados Unidos; Australia; Brasil.

\section{Raison et sentiment dans les différends normatifs}

\section{Résumé}

Au cours des cinquante dernières années, l'anthropologie s'est engagée dans d'intenses débats sur les fondements rationnels sur lesquels repose la compréhension ethnographique. Quel que soit le volet particulier pris par les interlocuteurs respectifs dans ces débats, la principale référence partagée par toutes les interventions est le caractère symbolique des données anthropologiques et de la compréhension. S’il en est ainsi pour n’importe quel contexte ethnographique, l'importance de se concentrer sur la pré-structure symbolique du monde de la vie est encore plus significative lorsque nous examinons les différends normatifs. Parce que, différemment des déclarations affirmatives sur des faits dans le monde, la signification des normes est antérieure aux intérêts de recherche de l'interprète et réside avant tout dans les visions du monde des sujets qui les partagent. Mes efforts de recherche sur les processus de règlement des différends ont montré que, ici, la raison et le sentiment s'emmêlent souvent, et leur bonne articulation est la condition pour rendre intelligibles les conflits respectifs Mots clés: raison; sentiment; différends; États-Unis; Australie; Brésil. 


\section{Reason and Sentiment in \\ Normative Disputes'}

\section{Luís R. Cardoso de Oliveira}

In the last fifty years, anthropology has engaged in intense debates about the rational grounds of ethnographic understanding. These include the exchanges that marked the so-called rationality debate in British anthropology, started by Winch's critique of Evans-Pritchard's interpretation of Zande's witchcraft (practices and thought). Debates also surged in response to Geertz's definition of ethnography as thick description, in an interpretive stance that was then critiqued by postmodernists. There are also the discussions over the recent ontological turn, which claims to radicalize the previous debates by emphasizing reflection, conceptualization, and experiment (Holbraad \& Pedersen 2017). Whatever the particular stand taken by the interlocutors in these debates, the main reference shared by all interventions is the symbolic character of anthropological data and understanding. Drawing mainly on Merleau-Ponty's vision of anthropology (1960: 112-123) as a discipline focused on the symbolic concreteness of practices and ways of life, I have argued that ethnographic description is basically dependent on an anthropologist's ability to apprehend and convey this concreteness in order to make it intelligible (Cardoso de Oliveira 2013a: 409-435). If that is so for any ethnographic context or fieldwork experience, the importance of focusing on the symbolic pre-structure of the lifeworld, or on the fact that social life is linguistically encompassed, is even more significant when we look at normative disputes. This is because, as Habermas (1990: 43-115) has pointed out, differently than assertoric statements about facts in the world, the meanings of norms exist prior to the research interests of the interpreter and these meanings lie primarily in the worldviews of the subjects who share them. Moreover, my research on dispute resolution processes has shown that reason and sentiment often become entangled. In such situations, as I will argue, the opposition between reason and sentiment is not only apparent, but its proper articulation is a condition for providing rational interpretations and making the respective conflicts intelligible.

Despite the fact that one often hears expressions emphasizing that emotional states or reactions obscure reality and must be overcome to make things intelligible, there seem to be experiences that do not make sense if we do not consider the emotions they provoke and/or the meaning they convey. This clearly contrasts with sentences such as: "she finally came to her senses" or "he was just letting out his spleen, and could not think properly," meaning that he was acting with anger, and we should not take seriously whatever he was saying.

The insightful aspect of sentiments and emotions comes wholeheartedly to the fore in conflicts or disputes in which moral aggressions play a major role. These disputes affect rights of an ethical-moral nature, which cannot be easily translated into material evidence, and whose assessment is beyond reach of the judiciary. Moreover, the breach of such rights is usually combined with a denial or devaluation of the dignity of the aggrieved. I have called such aggressions acts of inconsiderateness or moral insults in my ethnographies of small claims courts in the USA, experiences of citizenship rights in Brazil, and demands for recognition in Quebec (Cardoso de Oliveira 2005). In all of these cases, demands for respect, considerateness or recognition share a focus on the quality of the relationship between the parties, which acquires an unacceptable character because this quality is perceived to be imposed on the victim or outraged citizen by the opposing party. As I have argued elsewhere, the demanding party rejects what is perceived as an inferior status in the realm of citizenship, and that denies her or his dignity, and most Western courts are not adequately prepared to deal with such claims (Cardoso de Oliveira 2018: 34-63).

1 Paper written for the $10^{\text {th }}$ Birthday conference of the Collegium. Institute of advanced studies of Lyon: Rationality in the Transnational World New Perspectives, through April 9-11, 2019. 
By the same token, it is interesting to note that in many traditional societies where conflict resolution is conducted by means usually considered not rational, or objective, like the consultation of oracles (as the Zande do), the hiring of the services of unwitchers (as in Bocage, France), or by performing ordeals (as among the Kabyé in Togo) the outcome could always be interpreted as an assessment of the quality of the relationship between the parties. ${ }^{2}$ Such an assessment is exactly what is screened out of legal cases in Western courts, where cases are usually narrowed down to their legal considerations. On one hand, the parties often have difficulty adequately formulating their complaints against the quality of the relationship that is perceived to have been imposed upon them. On the other hand, the judiciary usually considers their emotive reactions to be nonsensical and at times as a sign of mental disorder.

The moral content of the expression of sentiments has been a classical theme in anthropology since the seminal essay by Mauss (1921), but its importance to understanding normative disputes first came to my attention when I analyzed small claims in Massachusetts (Cardoso de Oliveira 1989). These were always civil disputes, in which indemnities were sought for breach of contracts or torts. Claims for under $\$ 50$ did not really make sense if we supposed that the main objective of the plaintiffs was to receive the amount sued for. This is because, given the minimum expenses required to pursue such claims in court, a successful claimant would, at best, recover the amount spent to file the claims. As successful claimants rarely got the full amount of their claims, winning these cases often resulted in a monetary loss.

Inspired by Strawson's discussion on experiences of resentment (1974), I suggested that the respective moral aggressions are more easily identified in the attitudes or intentions of the actors than in their actual actions or behavior (Cardoso de Oliveira 2005). ${ }^{3}$ Therefore, not being able to present material evidence of the aggressions suffered, the plaintiffs in these claims took the opportunity of a court hearing to complain about one of two things. One was the insulting attitudes of the defendants, which they had difficulty to demonstrate and were not intelligible to the judge on legal grounds, and did not receive any effective compensation for the main aspect of their claims. In the other types of cases the plaintiffs sought some sort of indirect relief by obliging their opponents to respond in court. But, in this case they would also not receive any actual compensation.

However, these were not the only claims in which the sentiments of the parties or the expression of their emotions were an important aspect of the disputes. In addition to the dimensions of rights and interests that are regularly addressed by courts, I have argued that legal disputes often have a third thematic dimension, which is recognition (Cardoso de Oliveira 2007a; 2007b), characterized by the parties' demands to be treated as worthy citizens: with respect, considerateness and fairness. When the failure to satisfy such expectations is perceived as a denial of the plaintiff's worthiness or dignity, placing the aggrieved party in a condition of inferiority, the latter often reacts with anger and outrage, strongly showing his or her rejection of the respective humiliation. As mentioned above, such moral insults constitute objective aggressions to rights of an ethicalmoral nature, the violations of which may be difficult to prove with material evidence, but may actually be significant aspects of all kinds of disputes, like the one in the following narrative.

This concerns a dispute between tenants who were room-mates who sued their landlady for not returning the security deposit after the room-mates vacated the rented apartment. ${ }^{4}$ The case is particularly interesting because the landlady, who was a successful businesswoman plainly functional in her daily businesses and activities, was considered by the court to be a completely unreasonable person, who was said to have lost her mind in court. At the time of my research (1984-1986) tenants were required to make a security deposit when signing their lease, after co-signing a statement with the landlord about the conditions of the rented premises. If, when leaving the apartment, the landlord could identify damages beyond regular conditions of

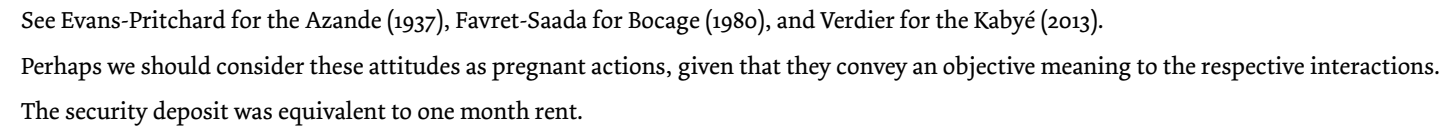


wear and tear, and having the statement as reference, the landlord could use the security deposit to repair the damages. However, if no statement had been agreed upon and signed by both parties at the beginning of the tenancy, the landlord could not demonstrate the alleged damages and would have to return the deposit, along with the interest accrued from the savings account where the money should have been placed. These were rules of strict liability, and if the landlord did not return the security deposit, the tenants could issue a "30-Day Demand Letter" which, if not observed, would allow the tenants to sue the landlord for treble damages.

That is exactly what happened in this case, which came to my attention when it was being tried on appeal to the Middlesex County Superior Court in Cambridge, Mass. after a Small Claims Court decision ordered the landlady to pay her former tenants three times the amount of their security deposit. Although she did not have the signed statement about the conditions of the apartment before the tenants occupied her property, the landlady alleged that not only had they damaged the apartment far beyond wear and tear, but that they had done so on purpose, because of the many disagreements that they had in the last months of their tenancy. Not having hard evidence to make her case, she made only ungrounded accusations and was absolutely outraged when the judge decided to suspend and postpone the trial until she found herself proper legal representation to handle her case. She had been granted permission to represent herself in the trial but not knowing the rules for presenting evidence, she was completely immobilized by the opposing lawyer, and the judge had to stop the session.

Since she challenged the judge with improper vehemence, he threatened to charge her with contempt of court to curtail her outburst and ordered her to leave the room escorted by a bailiff. As she left, she complained aloud and insistently about the judge. His clerk left here alone affirming: "I've had it...I've had it..." When commenting on this case, he and the other clerical workers said that "she just wanted to have her day in court", which is an expression with double meaning. While it emphasizes an important right of citizens to be heard in court (by the state), it also refers to claims that do not make sense, but which the claimants insist on pursuing.

Having lost the case in Small Claims Court for not being able to demonstrate the alleged damages, which the tenants refused to acknowledge, she became furious when the court awarded them treble damages and could not accept losing the case on a technicality, as she perceived it. The perception of not having been properly heard twice (that is in small claims and superior court where the case was suspended) stimulated a sense of unfairness and abuse that could not be argued in court, given the lack of admissible material evidence to support her claims according to court procedure.

In addition to the material loss that she could not demonstrate, she could not accept that the alleged abuses by the tenants were accepted by the court. The fact is that these alleged abuses were not even discussed, given the lack of adequate means to deal with them, as if they were not real aggressions, ${ }^{5}$ having been completely dismissed by the court. This explains her outrage as she left the court. But, the difficulty to pursue such claims in court and the lack of legal and judicial measures for dealing with the expression of emotions and sentiments is not limited to US courts or to the common law tradition, as we will see below, when we discuss "unusually persistent complainants" in Australia and a civil case in Brazil.

The invisibility of moral insults is widespread in Western courts, where emotional reactions and the mobilization of sentiments tend to be pathologized. A case in point is the work of a group of Australian psychiatrists who sought to revive the category of the querulant or paranoid litigant (Lester at. al. 2004), which they claim has been out of usage since the second half of the last century, but which seems to fit well a significant group of persistent complainants who were tracked down by a number of complaints organizations, which receive secondary referrals after an initial attempt to resolve the problem is unsuccessful. Besides having tried to clearly distinguish the unusually persistent complainants from a control group with the help of complaints

5 In an important essay, Berger (1983: 172-81) calls attention to the near impossibility to sue people for insults to honor in countries like the USA, where, given the lack of material evidence, they appear to be unreal aggressions. 
officers from six ombudsmen's offices in Australia (Idem: 353), the authors claim that different from other complainants, the persistent complainants are seeking vindication and retribution, which would go beyond the aim to deliver reparation and compensation that characterize courts and complaint organizations. ${ }^{6}$

But, should we not consider the fact that, given the difficulty to characterize the rights that actually have been injured, the allegations about which are usually not properly heard, certain complainants are left without many options. Being unable to obtain legal recourse or compensation, doesn't it seem that these complainants resort to retribution and vindication out of despair?

The complaints officers were asked to respond to a questionnaire about those they had identified as unusually persistent complainants from a sample of non-active cases and then to select control cases from their files that came right after each of the former ones, involving subjects of the same gender, about the same age and with similar complaints, whose case was also closed. An identical questionnaire was used for the control cases as well. However, these questionnaires were basically limited to inquiring into external aspects about how the claims were filed or processed. In terms of the perception of the parties, the material is organized according to excessively formal criteria. As I will argue, such criteria are not conducive to an adequate apprehension of the meaning of demands associated to the dignity of citizens, or to the respective demands for recognition, which are significantly dependent on processes of symbolic elaboration. Therefore, the material presented does not allow one to distinguish between would be pathological or nonsensical actions and meaningful and plainly logical emotional reactions, motivated by a failure to convey the aggressions or moral insults suffered that fall under the thematic dimension of recognition.

Thus, the study found that demands by the persistent complainants took an average of 35 months to reach an outcome, while the average time for the control group was just 8.3 months. Only $23 \%$ of the cases filed by the persistent complainants were considered to be resolved at the end of the process, while in the control group $87 \%$ were considered resolved. Moreover, persistent complainants visited the ombudsmen's offices without an appointment much more frequently ( $31 \%$ vs $4.5 \%$ ), and used more forms of communication (e-mail, fax, letters etc.), considering that $60 \%$ of these complainants sent more than 10 letters, compared with $9 \%$ of the control group. And $25 \%$ of the letters sent by the persistent complainants have more than 100 pages, against only $2.7 \%$ of the letters sent by the control group. Moreover, $52 \%$ of the persistent complainants requested to change their case workers during the process, compared to $19 \%$ of the other complainants.

All these indices show significant differences between the two groups in terms of the efforts of the complainants when pursuing their causes, or the emphasis with which they state their claims and their respective complexity, in view of the amount of time spent in pursuing them. However, they say nearly nothing about the causes themselves. Although the data on the nature of the injuries and on the objectives of the reparations sought reveal very similar figures in certain aspects, the tables below also show important differences that must be explored beyond the behavioral stereotypes examined until now in this article. ${ }^{7}$

\footnotetext{
6 The discussion of these Australian cases draws greatly on my former analysis of them that is partly reproduced here (see Cardoso de Oliveira 2013a: 422-26).

7 The two tables were designed by me, using the data and the indices presented in the paper (Lester et al. 2004).
} 


\section{Comparative Table I}

\begin{tabular}{l|c|c|}
\hline Type of Injury or Damage & Persistent Complainants & Control Group \\
\hline Financial loss & $71 \%$ & $72 \%$ \\
Damaged personal relations & $25 \%$ & $18 \%$ \\
Damage to physical health & $15 \%$ & $5 \%$ \\
Social \& economic damages in everyday life & $35 \%$ & $9,5 \%$ \\
Damages to self-esteem & $40 \%$ & $14 \%$ \\
Damages to health in general & $44 \%$ & $23 \%$
\end{tabular}

\section{Comparative Table II}

\section{Demands for Reparation}

Financial compensation

Improved services

Apologies and acknowledgement of mistreatment

Acknowledgement of social implications

Public recognition

To prosecute the case worker or have them fired

Public exposure and humiliation

Justice based on principles

To have a day in court

Reasons for the claim that vary over time

\section{Persistent Complainants}

Control Group

$\begin{array}{lc}61 \% & 58 \% \\ 42 \% & 47 \% \\ 67 \% & 32 \% \\ 39 \% & 9 \% \\ 25 \% & 0 \% \\ 43 \% & 11 \% \\ 14 \% & 0 \% \\ 60 \% & 18 \% \\ 25 \% & 4 \% \\ 31 \% & 0 \%\end{array}$

In fact, there is no significant variation in the percentages for the two first items in each table, but the differences in the other items are quite suggestive. While there is not much difference in the perception of material damage (financial loss) between the two groups or about the appropriate reparation (financial compensation), the consequences, suffering and encompassing demands for reparation present major differences between the persistent and the control groups. The last three items in the table on types of injury or damage are particularly meaningful concerning the experience of suffering affirmed by the respective complainants, and suggest differences in the very definition of the rights involved. The persistent complainants not only felt much more injured or impaired by the socio-economic impact of the damages and the respective consequences for their health, but they also indicate a broader impact related to their self-esteem ( $40 \% \mathrm{vs} 14 \%$ ), which constitutes one of the most sensitive aspects related to demands for recognition. Self-esteem directly affects a person's dignity, and as I have indicated in a few publications, has an important role in claims for the right to be treated with respect and considerateness (L. Cardoso de Oliveira 2005; 2007a; 2007b; 2013b). ${ }^{8}$

As I see it, the second table makes clear that the ombudsmen offices have considerable difficulties in understanding the significance of the persistent complainants demands that are related to the thematic dimension of recognition that I mentioned above. With the exception of the seventh line, which demands public exposure and humiliation of those responsible for the damages - revealing a clear motivation to achieve vengeance, which was present in $14 \%$ of the demands made by the persistent complainants - while nothing of the kind is found among the control group, all the other items in the table may be interpreted as measures to repair the parties' dignity, which was perceived to be threatened in the disputes.

8 Demands of rights for recognition have gained a great deal of attention in the literature since the 199os, with particularly important contributions by Taylor (1994), Honneth (1996) and Fraser (2003), in which dignity, self-esteem and identity gain central relevance in the respective formulations. 
But such claims and their significance are usually invisible to the courts and complaints organizations. This clearly seems to be the case regarding the demands for apologies and an acknowledgment of mistreatment, and for public recognition of the need for reparation.

The demand for justice based on principles is similar, as well as the request "to have a day in court" in either of the two meanings usually attributed to the expression, as mentioned above. The apparent confusion identified in just some of the cases filed by the persistent complainants, who changed the nature and the grounds of $31 \%$ of their claims during the process, could also be recognized as an effort to make oneself understood in a context adverse to acknowledging rights associated to the dignity of the citizen.

The indices that express the perception of the officers who receive the claims strengthen the argument that the Australian ombudsmen offices have difficulty adequately addressing the demands for reparation from the persistent complainants, and which I would associate to the dignity of the parties and the invisibility of moral insults, as suggested above. In $31 \%$ of the cases filed by persistent complainants the officers believed that there was no substantial loss, compared with $9 \%$ of the cases filed by the control group. Only $10 \%$ of the claims filed by persistent complainants were considered coherent and rational in the interviews, whereas $82 \%$ of the claims in the control group were described as rational and clear. By the same token, the data about the difficulty the officers have interacting with the persistent complainants are even more impressive: a) in just $12 \%$ of the cases was the relation with the persistent complainants classified as positive, compared with $86 \%$ of the cases in the control group; b) in $52 \%$ of the persistent cases the officer sought help from a more experienced colleague, but in only $2 \%$ of the other cases; and, c) in $48 \%$ of the persistent cases the officer avoided contact with the claimant, which was not identified in any of the control group cases.

Other characteristics in the presentation of the demands highlight major differences between the two groups and contribute to exoticizing the persistent complainants. These include very lengthy texts that are difficult to follow (95.5\% vs 17\%), "various oddities of writing also on occasion rendered parts of the letters from the persistent group unintelligible" (Lester at al. 2004: 354); rhetoric about having been treated in an unacceptable manner; "endorsements of their good character and personal diaries"; excessive use of different colored highlighters to accentuate certain words and others. Moreover, certain behavioral aspects are almost exclusively confined to the persistent complainants: direct or indirect threats to the officers (made in writing, on the telephone or in person), threats of suicide, and the use of excessively dramatic expressions. I would like to call attention to the fact that, with the exception of the threats against the officers and the demands for vengeance, which only appear in the cases of persistent complainants, all of the other indices (except for the demand for public recognition in Table 2) are also present, to a certain extent, in the control cases, suggesting an important area of intersection between the demands articulated by the two groups of complainants.

I understand that this area of intersection encompasses the thematic dimension of recognition and the rights associated to the dignity of the citizen that do not have the same importance in the control group cases as they do in those of the persistent complainants. I recognize that some complainants in the persistent groups may have had psychological problems of a diverse nature and seriousness, but that, probably, in most of the cases classified as persistent, the main problem of the complainants was that the ombudsmen offices were completely lacking in adequate procedures to deal with the respective demands. This might be true even in the cases where the complainants could be clearly diagnosed, through clinical examination, with paranoia or another form of psychosis. At any rate, irrespectively of the proper classification of these complainants, the fact that their claims could not receive an adequate response from the respective institutions, due to the entanglement of reason and sentiment, shows a significant institutional deficit for dealing with moral insults and suggests very interesting sociological problems. 
I would like to finish this paper with a brief reference to a civil case brought before a local court in Curitiba, ${ }^{9}$ the capital of Paraná state in Brazil. This is a case in which the plaintiff, a low-income urban worker, bought a small piece of land on the outskirts of the city from a real estate company that owns a large area designated for low-income housing, and built a shack. He moved in and a few months later the area was completely flooded by a storm, causing major losses for him and his neighbors. Most of his furniture and appliances were damaged and he visited the company office to undo the transaction, expecting to get back his down payment - but this request was denied. He had bought the property on a sunny day and was led to believe that the area had a good drainage system and was not subjected to floods. Given the company's refusal to return his down payment he first went to the consumer protection agency, but found no help there and filed a claim in court. The company then agreed to return almost the entire down payment, but he only received it nine months later and during this time he filed another claim for moral damages and the series of losses he had incurred during the time elapsed.

However, once in court, the plaintiff had difficulty to present his case without telling the judge about all his suffering and hardship since the flood and the beginning of the conflict with the company, and did not present clear evidence from the point of view of the court, and the judge could not understand his narrative. His unusual manner in presenting his claim, already noted in the manuscript he presented when the claim was filed, did not allow the judge to connect his story to the alleged incidents that supported the claim. The judge suspended the hearing and conditioned the possibility of a second hearing on the plaintiff's agreement to undergo a mental health evaluation by the district attorney's office psychologist. The plaintiff agreed, and the psychologist affirmed that the plaintiff's actions and perspectives were completely compatible with his situation, and emphasized that the plaintiff has a firm "belief and hope in the functioning of the judicial system and shows respect for the existing norms".

Nevertheless, the plaintiff did not perform as expected in the second hearing as well and engaged in intense discussions with the new judge, who also did not understand the plaintiff's narrative and dismissed his case. The plaintiff did not give up and filed two other claims. Since in his fourth attempt the company had changed its position, given the necessity to resell the disputed piece of land, it agreed to pay a larger indemnity to have the plaintiff off the property. The interesting thing now is that, in spite of this final legal victory, the plaintiff did not feel that the indemnity was adequate compensation for what he had been through and built a new shack on the very same lot after cashing the company's check for the returned down payment and an indemnity.

Irrespective of the legal aspects of the case, the fact is that because at no time in the process did the court properly address the objective abuses the plaintiff suffered from the company, he continued to fight for the recognition of the breached rights that never received proper repair. In a way, his behavior may also be interpreted as an act of vengeance, given that he inverted the roles with the company, which may have to file a suit to remove him. But I would argue that, similarly to the unusually persistent complainants in Australia, litigants or complainants have few options because aggressions to rights related to moral insults remain invisible in most Western courts. In addition, the complainants' actions and attitudes make it very difficult to distinguish acts of vengeance from demands for repair and recognition.

No matter how we look at the cases discussed above, it is clear that understanding the respective claims and repairing the eventual acts of disrespect to these rights, characterized as moral insults, requires an articulation between reason and sentiments or emotions. This is true for disputes between tenants and landlords in the USA, those involving persistent complainants in Australia, and low-income plaintiffs trying to get indemnities in Brazil.

9 "Juizado Especial Cível" (Special Civil Court), whose procedures are somewhat similar to Small Claims Courts in the USA, and the parties do not need legal representation. The case is taken from a very interesting ethnography on consumer claims by Ciméa Bevilaqua, which has a detailed description of the case (2008: 159-173). 
Received: December 29, 2020

Accepted: February 17, 2020

Revised by Jeff Hoff

\section{Acknowledgements}

I would like to thank the reviewers, as well as Wilson Trajano Filho and Stephen Baines for their comments to a first draft of the paper.

\section{References}

BERGER, Peter. 1983. "On the Obsolescence of the Concept of Honor”. In: S. Hauerwas \& A. MacIntire (eds.) Revisions: Changing Perspectives in Moral Philosophy. Indiana: University of Notre Dame Press. pp. 172-81. BEVILAQUA, Ciméa. 2008. Consumidores e seus Direitos: Um estudo sobre conflitos no mercado de consumo. São Paulo: Humanitas/ NAU.

CARDOSO DE OLIVEIRA, Luís. R. 1989. Fairness and Communication in Small Claims Courts. PhD dissertation, Harvard University, Ann Arbor: University Microfilms International, pp. 495 (order \# 8923299). . 2005. Droit légal et insulte morale - Dilemmes de la citoyenneté au Brésil, au Québec et aux États-Unis.

Québec: Les Presses de l'Université Laval. 172 pp. (ISBN 2-7637-8219-1). . 2007a. "Honneur, Dignité et Réciprocité". In A. Caillé (org.), La quête de reconnaissance : nouveau phénomène social total. Paris: Éditions La Découverte. pp. 89-103. [ISBN 978-2-7071-5332-6]. . 2007b. "Peut-on parler de violence sans agression morale?". Vibrant - Virtual Brazilian Anthropology, 4(1): 5-26. Janeiro a Junho de 2007, ISSN 1809-4341. . 2013a. "Concretude Simbólica e Descrição Etnográfica (Sobre a relação entre antropologia e filosofia)". Mana, 19(3): 409-435. ISSN 0104-9313. . 2013b. "Equality, dignity and fairness: Brazilian citizenship in comparative perspective". Critique of

Anthropology, 33(2): 131-145. DOI: 10.1177/0308275X13478221. ISSN: 0308-275X. . 2018. "Sensibilidade Cívica e Cidadania no Brasil". Antropolítica: Revista Contemporânea de Antropologia, 44(1): 34-63. Rio de Janeiro - ISSN 2179-7331.

EVANS-PRITCHARD, Edward E. 1937. Witchcraft, oracles and magic among the Azande. Oxford: The Claredon Press.

FAVRET-SAADA, Jeanne. 1980. Deadly Words: Witchcraft in the Bocage. London: Cambridge University Press. FRASER, Nancy. 2003. «Social Justice in the Age of Identity Politics: Redistribution, Recognition and Participation". In: N. Fraser \& A. Honneth, Redistribution or Recognition? A Political-Philosophical Exchange. London: Verso. pp. 7-109.

HABERMAS, Jürgen. 1990. "Discourse Ethics: Notes on a Program of Philosophical Justification". In: Moral Consciousness and Communicative Action. Cambridge: MIT Press. pp. 43-115.

HOLBRAAD, Martin \& PEDERSEN, Morten. 2017. The Ontological Turn: An Anthropological Exposition.

Cambridge: Cambridge University Press. 
HONNETH, Axel. 1996. The Struggle for Recognition: The Moral Grammar of Social Conflicts. Cambridge: MIT Press.

LESTER, Grant; WILSON, Beth; GRIFFIN, Lynn \& MUL-LEN, Paul E. 2004. "Unusually persistent complainants". British Journal of Psychiatry, 184: 352- 356.

MAUSS, Marcel. 1921. "L'expression obligatoire des sentiments (rituels oraux funéraires australiens)". Journal de Psychologie, 18: http://classiques.uqac.ca/classiques/mauss_marcel/essais_de_socio/T3_expression_ sentiments/expression_sentiments.pdf pp. 2-8.

MERLEAU-PONTY, Maurice. 1960. “De Mauss à Claude Lévi-Strauss.” In: Signes. Paris : Les Éditions Gallimard, pp. 112-123.

STRAWSON, Peter. 1974. "Freedom and Resentmen". In: Freedom and Resentment, and Other Essays. London: Methuen \& Co. LTD. pp. 1-25.

TAYLOR, Charles. 1994. “The Politics of Recognition”. In: A. Gutmann (ed.), Multiculturalism and the Politics of Recognition. New Jersey: Princeton University Press. pp. 25-73.

VERDIER, Raymond. 2013. "L'Invisible, la Nature et ses Justices”. In: R. Verdier, N. Kálnoky \& S. Kerneis (eds.), Les Justices de L'Invisible. Paris: L'Harmattan. pp. 15-44.

Luís R. Cardoso de Oliveira

University of Brasilia - Anthropology Department

https://orcid.org/0000-0002-2152-0991

Author's corresponding address: Irco.300o@gmail.com 